Tomislav Stojanov, tstojan@ihij.hr, tstojan@gmail.com Institute of Croatian Language and Linguistics Republike Austrije 16, 10.000 Zagreb, Croatia

\title{
Orthographies in Grammar Books - Rationalism and Enlightenment
}

\section{Summary}

This work describes the orthographic content in grammars of European languages in the $17^{\text {th }}$ and the $18^{\text {th }}$ century. Reviewed were 17 grammars for 7 languages in Rationalism, 15 grammars for 11 languages in the Enlightenment, and 12 Latin orthographies. As for orthographic entities in the broader sense (orthography as a way to write down speech), our starting point were orthographic grapheme units which are contrasted to meaning (i.e. orthographic entities in the narrower sense, e.g. punctuation).

Contrary to the traditional description which focused on spelling, this work observes the beginnings of orthographic content in grammars and its development into an autonomous language phenomenon and norm. The strong connection between orthography and grammar is described and it is established that, from the diachronic point of view, orthography cannot be integrally reviewed without studying the grammatical teachings.

Keywords: orthography, grammaticography, punctuation, language norm, literacy, rationalism, enlightenment

\section{Introduction}

In addition to being extremely poorly described in linguistic historiographic literature, the main motive for studying the development of orthographic content in grammar books lies in the fact that in linguistic historiography it is spelling which has primarily been studied. ${ }^{1}$ In this work, orthographic content is methodologically and terminologically divided into two groups. Orthography in the broader sense refers to the understanding of orthographic entities as units connecting the grapheme and the phoneme level (i.e. the way to write down sounds). On the other hand, the relation between grapheme and meaning relates to orthography in the narrower sense. This work primarily researches the latter aspect, that is its occurrence in old grammar books: punctuation, writing of capital and minuscule letters, italics, etc. Introducing this distinction enables a grammatographic comparison of orthographic content between different languages and makes it possible to follow the development of literacy in time. The development of punctuation, for example, is one of the issues which clearly point to changed patterns of writing and literacy, respectively. ${ }^{2}$ The discipline which studies orthography in the narrower sense could be called orthographology or orthographographia.

The history of grammar books is reviewed in two periods - Rationalism and the Enlightenment - which had great impact on the development of grammatography and its orthographic content. Their historical sociolinguistic context is described. After the Antiquity and the humanistic Renaissance, Rationalism is the third great period of orthographic evolution, which brought about a great deviation from traditional orthographic content in grammars. It is followed by the Enlightenment, in which grammars and orthographies were given a prescriptive and educational function. Although other

\footnotetext{
${ }^{1}$ Review of the consulted reference literature can be seen in the $6^{\text {th }}$ footnote of Stojanov (2018).

2 ,Punctuation was developed by stages which coincided with changing patterns of literacy“ (Parkes 1992: 2)
} 
grammars occurred during the $17^{\text {th }}$ and $18^{\text {th }}$ century, which according to their typology belonged neither to Rationalism nor to the Enlightenment, these two ideas had such sociocultural importance in the European society that they can be observed independently.

The linguistic historiographic literature which we used were Kovachich (1786), Marsden (1796), Swiggers (2001), and Haßler \& Neis (2009), with independent collection of sources for Rationalism and the greater part of the Enlightenment.

Since the Enlightenment generated many national orthographic prescriptive books, for the understanding of orthographic content it was necessary to provide a short overview and describe the coming into being of separate orthographic manuals in previous periods. Latin orthographies had a great impact on the orthographic content in grammars, which lead to the development of national orthographic manuals in the $17^{\text {th }}$ century as we know today.

\section{Rationalism}

Through great scientific discoveries, especially in mathematics and astronomy, Renaissance Humanism was replaced by the period of Rationalism in the $17^{\text {th }}$ century. Verburg (1998: 233) points to Kepler and Galileo as the notional beginnings of Rationalism. If language was the medium to bring about Renaissance Humanism, in Rationalism this role fell to philosophy, especially Descartes, Spinoza, Leibnitz and other authors. Some earlier Latin grammars (e.g. Scaliger, Sanctius, and Scioppius) can also be characterized as philosophic grammars ${ }^{3}$, however it was the Port-Royal Grammar which exerted a much greater influence in the $16^{\text {th }}$ and $17^{\text {th }}$ century than Latin grammars, which is why it is placed into the centre of Rationalism. ${ }^{4}$ The most important representative of the rationalistic grammar is the French grammar from 1660 Grammaire générale et raisonnée, generally known as the Port-Royal Grammar, by authors Charles Lancelot and Antoine Arnauld. Since it was profoundly influenced by Descartes, it is also called rationalistic. The fact that the grammar was written by two authors, one grammarian and one philosopher, paints its profile. Since the focus is on the spoken, and not on the written language, the content is logically described through the spoken dimension. Besides spoken language as the starting point, three other key orthographic points can be observed in rationalistic grammars: striving towards a universal description, the comparative approach, and the didactical perspective.

Thinking about the theory of universal grammar was primarily a French discipline ${ }^{5}$, so the rationalistic idea can well be presented already by studying the grammatical activities in French and the languages under its influence.

In the Port-Royal Grammar, orthographic content is not separately dealt with. Only the issues of capital and minuscule letters, and roman or italic writing are addressed within the discussion of letters as signs (chapter V). Although it primarily describes French, with occasional examples from other languages, it does not include orthographic description since it is designed to contribute to the description at the meta-level as a general and reasoned (philosophic) grammar - générale et raisonnée. Capital and minuscule letters, and roman and italic writing are typographically universal, hence its inclusion in the

\footnotetext{
${ }^{3}$ Rowe (1974: 366)

${ }^{4}$ Vinja (2000: 7)

The preparators and translator of the Port-Royal Grammars into English (Arnauld and Lancelot 1975) convey the words of Pierre Juliard (1970), who wrote that this grammar set the basis for almost all linguistic work in the $18^{\text {th }}$ century.

Also, this grammar exerted great influence on the linguistic theory of Noam Chomsky, who referred to it often (especially Chomsky 1966).

${ }^{5}$ Swiggers (2001: 618)
} 
grammar. In grammatographic sense, it breaks tradition with the Antiquity as grammar loses its definition as ,the art of reading, writing and speaking correctly“. Grammar is only defined as the art of speaking (l'art de parler), and speaking means, as is stated in the very beginning of the work, expressing your thoughts using signs which people have invented for that purpose. ${ }^{6}$ Arnauld and Lancelot argue that the most convenient (les plus commodes) of these signs are sounds and vocals, pushing the written language into the background. The primacy of spoken language over writing has longstanding tradition and dates back to the Antiquity, with the major difference that then it was about "the art of speaking correctly" (ars pure loquendi), as can be found, before Arnauld and Lancelot, in Sanctius, Alsted, and Scioppius. In his Grammatica philosophica, Scioppius divides grammar, instead of the then usual orthography, prosody, etymology, and syntax, into orthoepy, prosody, etymology, and syntax. ${ }^{7}$ Letters have only the "secondary" function of marking unstable and invisible sounds.

The Port-Royal Grammar was preceded by two grammars of Claude Lancelot $(1644,1655)$, and it was followed by another two grammars by the same author (Lancelot 1676a, 1676b). In them, a change in looking at the orthographic content can be observed.

The Greek grammar from 1655 starts with the studies on letters and syllables (Des lettres \& des syllabes), but it does not mention orthography. The orthographic content which is described, but not called orthographic, is found in chapter XI, where the apostrophe is described in the context of omitting sounds in syllables. In a later edition (found in the 1754 edition), orthographic content has been supplemented by a chapter XII, describing also separation marks (marques de separation) as two dots on top of a word (dialysis or dissolutio), and a comma which separates syllables (diastole), connecting marks (marques de réunion) in the form of a hyphen at the end of the line, and the mark subunio connecting words, marks for diacritical lines with dots marking proper names (diacritical line with one dot for names of persons and nations, with two dots for mountains, with three dots for seas, rivers and lakes), and marks for dialogues in the form of the letters of alphabet. Chapter XIII is about connecting and abbreviating the writing of letters.

The Latin grammar from 1644 describes orthographic content in book IX (Traite' des lettres et de la maniere d'e'crire \& de prononcer des Anciens) in three chapters. Chapter XIII is about orthographic criteria of reason (raison) and authority (autorité). Orthography pursuant to reason describes original spelling pursuant to the etymology of the word (e.g. deliciae is written with $c$, not with $t$ because it stems from delicatus). Orthography pursuant to authority means following the spelling written by good authors (les bons auteurs), e.g. Cicero and Vergil. The chapter also contains 4 pages of advice for spelling Greek names. Chapter XIV describes some general issues in orthography: writing of capital and minuscule letters, using letters for marking names (e.g. letter A for the male name Aulus, P. R. for Populus Romanus), superlatives (e.g. B. B. means bene, bene, i.e. the best, optimi) or important places in a book (e.g. L. L. as locus, laudabilis, similar to the Greek use of the letter $\mathrm{X}$ or $\Theta$ for the place of censure or shame), dividing words into syllables, and writing of the apostrophe, two dots above a word, and the hyphen. Chapter XV (De la punctuation) explains punctuation as "la maniere de ponctuer" introducing dots for creating breaks. Those are comma, colon, period, semicolon, and question mark and exclamation mark.

Two grammars published after the Port-Royal grammar were grammars for Italian and Spanish language. The Italian grammar from 1676 contains 4 pages of orthography in the second chapter

\footnotetext{
${ }^{6}$ „Parler, est expliquer ses pensées par des signes que les hommes ont inventés à ce dessein.“ (translation by Vinja 2000: 36).

${ }^{7}$ In the 20th century Saussure's structuralism also put the spoken language into the foreground. According to Saussure „the speech act always precedes“ (CLG 37), and ,it is necessary to start with examining speech“ (note 65 in Saussure 2000).
} 
entitled Quelques regles importantes pour l'Ortographe, \& pour l'analogie des mots pris du Latin [,,some important rules concerning the orthography, and the analogy of words derived from the Latin"]. ${ }^{8}$ The phonological aspects are described (e.g. pronouncing astinenza instead of Latin abstinentia) and notes on writing of double letters are provided.

The Spanish grammar marginally mentions orthography on half a page in the fourth part of the first chapter dedicated to letters and pronunciation (Recapitulation des regles de la prononciation), where, in comparison to Latin, some observations on pronunciation are also provided (e.g. ciencia to scientia).

As can be seen, the Italian and Spanish grammars have a significantly different view of orthographic content from the Greek and the Latin. The latter ones mostly inherit the tradition of orthographic description, while the same issues (e.g. abbreviation of writing, punctuation, etc.) are not included in the teachings of vernacular languages. The model of a general and reasoned grammar can be recognized in the method of comparison with Latin and in descriptions of common or similar characteristics between different languages, which should be helpful in learning a new language. After Greek and Latin, French was considered to be "prestigious" in the $17^{\text {th }}$ century Europe and was supposed to be the indicator of the model from which grammatical teachings are to be spread.

Other rationalistic grammar, which came into being under the influence of the Port-Royal Grammar, do not deviate from their source either. For example, the French grammar Beauzée (1676), whose title in the English translation reads „General Grammar, or Explanatory Account of the Necessary Elements of Language, designed as a basis for the study of all languages", deals with orthography in the first book (Des Eléments de la Parole) in the context of a general discussion of sounds and writing of capital and minuscule, and roman and italic letters. This author, as stated by Swiggers (2001: 619), even made a distinction between orthography (study of letters, diacritical signs, use of type of letters) and orthology (lexicology and syntax). Tooke (1786) does not have any orthographic content either.

Two later rationalistic grammars, which emphasize the educational dimension in their titles, Sacy (1799) and Roth (1799), do not have any orthographic content, and following the Port-Royal Grammar they accept the form of a discussion, by which they exclude orthographic content already on the grammatographic and methodological level. ${ }^{9}$ Sacy points out in the title that the book is intended for learning all languages, while Roth emphasizes the systematicality of learning and divides the grammar only into etymology and syntax. Beattie (1788) for English can be put into a similar educational category, saying in the preface that ,it may be particularly useful in [s]chools". He does not include any orthographic descriptions either.

Rationalistic grammars, as can be seen, appeared also in the $18^{\text {th }}$ century, which was marked by the educational prescriptive idea of the Enlightenment, which is dealt with in the following chapter. According to Swiggers (2001: 620), three grammatical "genres" can be distinguished in $18^{\text {th }}$ century France: (i) practical grammars (elementary and contrastive grammars), (ii) "reflective grammars" (philosophical grammars), and (iii) synthetizing and normative grammars (combination of the first and the second). A part of the grammars considered by Swiggers as prototypical, are rationalistic, while others belong to the Enlightenment. Based on their orthographic content, this can be clearly shown.

Among the reflective grammars, Swigger emphasizes Buffier (1709) and Girard (1747). Buffier has an orthographic chapter Principes pour l'ortographe on pages 101-118, however it comprises a very basic

\footnotetext{
${ }^{8}$ According to the English translation of the 1750 edition.

${ }^{9}$ Explaining his criteria for categorizing grammar books, Rowe (1974: 362) says that in Rationalism it is not easy to determine what is, and what is not a grammar book.
} 
discussion, without any description of specific written signs. Girard does not mention orthography at all.

Among practical grammars, Swiggers includes Restaut (1730), Wailly (1754) and Lhomond (1780), of which only the first one has rationalistic characteristics according to the criteria of the title and the definition of grammar. ${ }^{10}$ All three of Swigger's representatives of practical grammars describe orthographic content in the narrower sense, with the orthographic chapter at the very end of the book (Wailly describes the teachings about the verse after orthography). Punctuation marks as the only orthographic content in the narrower sense are part of the orthographic chapter, but are described separately. Restaut's grammar ends with the chapter XVI, which is divided into 4 units describing orthography (pages 234-284), accent signs, punctuation marks (one group encompasses the comma, semicolon, colon, period, question mark and exclamation mark, and the other the apostrophe, hyphen, diaeresis, cedilla, and brackets). Wailly (1754) described orthographic content in the chapter De l'orthographe on pages 335-369. ${ }^{11}$ For him, orthographic characters are the signs for accents, diaeresis, apostrophe, brackets, capital letters and punctuation marks (comma, period, semicolon, colon, question mark, and exclamation mark). In his short grammar of only some 90 pages, Lhomond (1780) also includes an orthographic chapter De l'orthographe on the pages 79-89. Orthographic units are considered the apostrophe, hyphen, diaeresis, cedilla, and brackets, while punctuation marks (comma, semicolon, colon, period, question mark, and exclamation mark) are described separately on two pages.

The representative of the third type of grammar according to Swiggers is Régnier-Desmarais (1706), whose orthographic chapter Du Traité de l' Orthographe is described on pages 75-136 and deals with orthography in the broader sense in the context of discussions on the reform of the French orthography. In this category we could include the English grammar by Brightland and Gildon (1711), for which Buschmann-Göbels (2008: 82) says that it is „a kind of mixture between a national and a rational grammar", which can be confirmed by our orthographic criteria. Grammar is determined as "the knowledge or art of expressing our thoughts" not containing orthography, however in chapter XI (Of Stops or Pauses in Sentences, and Abbreviations of Words) it lists "four stops or pauses" - period, comma, colon and semicolon - and continues to list also other sentence marks: question mark, exclamation mark, round brackets, hyphen, apostrophe, the sign ^ which does not have a distinct name, but is written under the sentence marking an omitted word in print or writing, a long line (-) which is written instead of a word or a name, then the signs for note in the margin, obelisk $\ddagger$ for references, $\S$ for sections, * (asterism) for an omitted part of the sentence, one or two single quotation marks (') and 9 for paragraphs. The chapter ends with a list of abbreviations and their meanings (e.g. St. for Saint).

Rationalistic grammars of the $17^{\text {th }}$ and $18^{\text {th }}$ century do not deal with orthographic content. The only exception is Buffier (1709), whose work can be placed among the transition grammars between Rationalism and the Enlightenment. The relation to orthographic description is an important indicator of grammar classification between Rationalism and the Enlightenment. Led by the increased interest for studying the differences between languages and cultures ${ }^{12}$, philosophic grammars led to

\footnotetext{
${ }^{10}$ In his Principes généraux et raisonnés de la grammaire françoise, Restaut defines grammars as l'art de parler, while Wailly already mentions good writing (l'art de parler \& d'écrire [...] sur le bon usage) and correct writing (l'art de parler \& d'écrire correctement).

${ }_{11}^{11} 1772$ edition used.

${ }^{12}$ Diderichsen (1974: 287)
} 
comparative linguistics. After dealing with the universal and descriptive grammar, the focus shifted to the national and the normative, which led to a completely new epoch of the Enlightenment.

\section{The Enlightenment}

The Enlightenment had different manifestations in European language environments. Further development of the orthographic and grammatical practice is primarily reviewed in those European countries and languages which demonstrate the effect of the Enlightenment in the most representative way. Those were environments where the Enlightenment brought about mass and compulsory primary education (Prussia and the Habsburg Monarchy) or in which academies were established with the goal of issuing normative grammars (the Netherlands, Poland, Russia, Spain, and Sweden). All listed environments share a common sociocultural feature, which is typical for the Environment: the occurrence of language prescriptivism and language standard. Except for the mentioned countries, the categorization will include other chosen language environments whose special features additionally illustrate the effect of the Enlightenment onto the evolution of orthographic content in grammar books (English, Portuguese, and Italian). Two English grammar books (Lowth and Webster) can de facto be called school normative manuals of their time. The remaining languages, those without normative grammars, are not separately dealt with in this research - for example French, which did have a language academy with the statutorily established goal of issuing a normative grammar, but did not issue one until 1930.

The Enlightenment is usually determined as the period from the death of King Louis XIV in 1715 until the beginning of the Napoleonic Wars (1804-1815). According to some characteristics, it can be reviewed together with the era of Rationalism and the progress of science ${ }^{13}$, however in this grammatographic typology, as will be seen, those are considered two distinct periods since the grammar books differ typologically in the perspective of orthographic content as compared to the rationalistic ones. The Enlightenment had a major impact on the change of social relations, which reflected clearly on grammatical teachings and the role of orthography in them. "One of the primary elements of the cultural interpretation of the Enlightenment is the rise of the public sphere in Europe “. ${ }^{14}$ The phrase "the domain of 'common concern'“, as argued by Habermas (2003: 387), is important for understanding the Enlightenment, and it is demonstrated in the strengthening of public administration and the laws, and in a better organization of government. The so-called Enlightened Absolutism refers to a type of autocratic government characterized by ideology of the Enlightenment. For example, one of the important political decisions of Enlightened Absolutism is that education is one of the (secular) tasks of the state, which lead to introduction of compulsory primary education, first in Prussia under the rule of Friedrich II in 1763 (for age 5 to 13), and then in Austria in 1774 under Maria Theresia (for age 6 to 12). This decision had far-reaching consequences for language: standardization of education assumed the standardization of language.${ }^{15} \mathrm{~A}$ regulated orthography was a mark of a regulated country, which wanted to supervise the educational process by means of a unique orthography. Since the Jesuits had until then the key role in the education in countries with a Catholic majority ${ }^{16}$, the secular rulers exerted great pressure on pope Clement XIV leading to the

\footnotetext{
${ }^{13}$ For example Delon (2001: 617-622), who describes grammatical learning in the Enlightenment integratively with Rationalism.

14 As stated in the publicly available anthology The Age of Enlightenment. An Anthology Prepared for the Enlightenment Book Club at http://www.rosenfels.org/The Age Of Enlightenment Anthology.pdf. Accessed on 10 February 2017.

15 „Through the standardization of the written word, knowledge could be standardized.“ Deak (2015: 24)

16 The Jesuits established numerous gymnasia, and they had an existing teaching standard, good financial possibilities, support of the influential Catholic Church and numerous scientists among them. The University of Zagreb, for example, was founded by the Jesuits in 1669 .
} 
suppression of the Society of Jesus in 1773, opening the path to a change of the educational paradigm. The second Catholic order whose work in schools and education overlapped with the interests of Enlightened Absolutism - the Pauline Fathers - met a similar fate in 1786 when it was suppressed by Joseph II of Habsburg.

The textbooks used in education had to be authorized, making grammar and orthographic books official for a certain state territory for the first time in history. Mass education affected the reconceptualization of grammatical teaching ${ }^{17}$, leading consequently to a changed role of orthography in grammar manuals. Grammar books were given a strong normative role, and orthographic books the status of prescriptive manuals. As conveyed by Williams (2005: 11), John Locke claimed in his work Some Thoughts Concerning Education from 1693 that the goal of the education is the preparation of the child for achieving future independence in the world. Thus the separation of orthographic and grammar content is not surprising: gaining basic literacy was separated from knowledge of grammatical rules on language structures.

\subsection{Normative grammars of language academies and other authorities}

One of the major characteristics of the Enlightenment is the spreading of establishment of language academies modelled on Accademia della Crusca (1572) and Académie Française (1634): Spanish (1713), Dutch (1766), Portuguese (1779), Russian (1783), Swedish (1783), Hungarian (1830), etc. The question of language was vital when establishing first academies, which can clearly be seen in their eminent lexicographic activities: Vocabolario degli Accademici della Crusca (1612), Le Dictionnaire de I'Académie française dedié au Roy (1694), and Diccionario de autoridades (1726-1739). It was in the countries in which academies had language authority that the first normative grammars were issued.

The first normative grammar of Spanish was published in 1771 - Gramática de la lengua castellana. The definition of grammar was "arte de hablar bien" (art of speaking well) and it did not contain any orthographic chapters. The first normative orthography is in the mentioned academy dictionary Diccionario de autoridades. As a separate work the orthography was issued in 1741, two years after the last, sixth volume of the dictionary entitled Orthographía española. ${ }^{18}$

The Russian academу Академия Российская commissioned Johann Werner Paus to write a grammar, which he did, but the grammar remained unpublished, although its manuscript had great influence on later grammarians. ${ }^{19}$ The first normative grammar intended „for use in the lower classes of the three gymnasia that were attached to Moscow University, the Army Cadet Corps and the Academy of Sciences ${ }^{\prime \prime 20}$ was written by Lomonosov (1757). Orthography can be found in the $2^{\text {nd }}$ chapter on pages 41-61, and it deals with letters/sounds, division of words, and with orthographic characters (comma, period, colon, semicolon, question mark, exclamation mark, hyphen, and brackets ${ }^{21}$ ). Orthography in the narrower sense is described on 4 pages in total.

The Polish model is unique because the manual of Polish with instructions for teachers was commissioned by the body Komisja Edukacji Narodowej [Committee for National Education], established in 1773 and known as the first Ministry of Education in Europe. Onufry Kopczyński (1778, $1780,1781)$ created a normative grammar for three grades of primary school. All three volumes deal with the description of sounds/letters, while the description of punctuation - comma, semicolon, colon, period, exclamation mark, question mark, hyphen, brackets, quotation marks [,], and mark for

\footnotetext{
${ }^{17}$ Williams (2005:13)

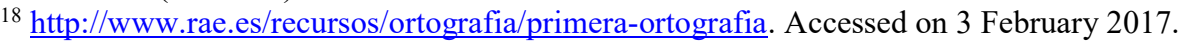

${ }^{19}$ Stammerjohann (2009: 1137)

${ }^{20}$ Quotation according to Marker (1994: 15), conveyed by Helden (2008: 153).

${ }^{21}$ Lomonosov emphasises square brackets, but in the grammar only round brackets are used.
} 
notes [(1), (a), $\left.\left({ }^{*}\right)\right]$ - is shortly described on 3 pages in the first volume within the first chapter on pronunciation (III. O Znamionach). ${ }^{22}$

The Dutch grammar Weiland (1805) has "been authorised by the government" and "remained the most authoritative one until the middle of the 19th century". ${ }^{23}$ In the first chapter (Over de spelling, pages 11-45) sounds and syllables are described. Orthographic content was described by Siegenbeek (1804) in the first official orthographic manual for Dutch.

The Royal Swedish Academy of Sciences (Kungliga Vetenskapsakademien, established in 1739), distinct from the Swedish Language Academy (Svenska Akademien, established in 1786), authorized the grammar of Sahlstedt (1769). ${ }^{24}$ It ends with a description of the division of words and of orthographic characters in chapters 15 and 16 (pages 96-99). Those were period, colon, semicolon, comma, brackets, apostrophe, and diaeresis.

\subsection{Normative grammars in compulsory schools}

The Prussian government commissioned Johann Christoph Adelung to create a school grammar, which appeared in 1781. The grammar is divided into two parts: first Vor der Fertigheit richtig zu reden [About the Art of Speaking Correctly] with a description of grammatical rules, and the second Von der Fertigheit richtig zu schreiben oder von der Orthographie [About the Art of Writing Correctly or About Orthography] on pages 573-626. The title of the chapter shows its pragmatic function. Grammar is also simply defined as "die Kunst, eine Sprache richtig zu reden und zu schreiben“ [Art of speaking and writing a language correctly]. Orthography is divided into five chapters: first on general orthographic rules, second on writing letters/sounds, including capital and minuscule letters, third on division of words, fourth on compound and separate writing, and fifth on punctuation. Punctuation marks are categorized into three categories: the first encompassing the question mark and the exclamation mark, the second the period, semicolon, and comma, the third quotation marks [,], the hyphen (Theilungszeichen) as = or -, round and square brackets, ellipsis (das Zeichen einer abgebrochnen Rede), dash (Gedankenstrich) or -, and apostrophe. Contrary to his predecessor Gottshed $(1749)^{25}$, whose work also has abundant orthographic content on some hundred pages, but in the beginning of the grammar, for Adelung orthography is a completely independent unit which he placed in the end of his grammar, and which already next year (1782) appeared in a separate publication entitled Grundsätze der Deutschen Orthographie. Adelung's most exhaustive work on German orthography is Adelung (1788) which covers 426 pages without dictionary.

The school reformer under the rule of Maria Theresia, Johann Ignaz Felbiger issued in 1774 a German normative grammar which does not include orthographic content because it came out in the same year as a separate, also normative work (Felbiger 1774). ${ }^{26}$ It consists of four parts: the first deals with writing of letters including capital and minuscule letters, the second is on the division of words, the third on punctuation, and in the forth there is an orthographic dictionary spanning 17 pages. This is a short and highly structured work of 40 pages, with obvious emphasis on transparency, clarity and exemplification. The orthographic content is presented in the form of rules with exceptions. Felbiger's

\footnotetext{
${ }^{22}$ The links to digitalized volumes of the grammar are here: https://gramatyki.uw.edu.pl/book/162. The first volume from the 1804 edition was used. Accessed on 29 March 2017.

${ }^{23}$ Noordegraaf (2000: 896)

${ }^{24}$ Teleman (2005: 1385)

${ }^{25}$ Digitalized version can be found here:

http://www.zeno.org/Literatur/M/Gottsched, +Johann+Christoph/Theoretische+Schriften/Grundlegung+der+deut schen+Sprachkunst (Accessed on 2 February 2017).

${ }^{26}$ Felbiger's grammar was issued in all languages of the Monarchy - first in bilingual editions, later as adapted translation. For more on Vienna grammars and Central European textbooks see Nyomárkay (2000: 119-128).
} 
grammar and orthography are a good indicator of the evolution of grammar books by separating orthographic content from grammatical teachings, and by the form of presenting the material as methodical prescriptive school manuals. Other orthographic authors in the Habsburg Monarchy also accepted this template in their prescribed school manuals. ${ }^{27}$ This orthographic work could be argued to be the predecessor of contemporary orthographic books (in those countries which have orthographic standardization in the form of separate orthographic manuals).

The Hungarian orthography (Révai 1778) was published before the grammar (Révai 1781) in which we do not find any orthographic content, as is to be expected.

The same applies to the anonymous Slovak school grammar Přjwod ku Dobromluwnosti Slowenské: $k$ Prospěchu Mládeži Slowenských Sskól from 1780, in which there is no orthography since in the same year a separate orthographic manual Přjwod ku Dobropjsebnosti Slowenského Pjsma k Prospěchu Mládeži Slowenských Sskól was published.

Croatian, which was also part of the Habsburg Monarchy, has three peculiarities: first, due to political separation it was separated on dialectical basis into a Kajkavian and a Shtokavian part ${ }^{28}$, second, only orthographic manuals, no grammars, were printed ${ }^{29}$, and third, those were bilingual orthographic manuals. All three facts serve well to paint the language-political situation of Croatian in the Habsburg Monarchy in the second half of the $18^{\text {th }}$ century. A Kajkavian orthography was published anonymously in 1779 entitled Kratki navuk za pravopiszanye horvatzko za potrebnozt narodnih skol (Einleitung zur croatischen Rechtschreibung zum Gebrauche der Nationalschulen im Königreiche Kroatien). ${ }^{30}$ A Slavonian (shtokavian) orthography was also published anonymously in 1779 (Antun Mandić was later established to be the author).

\subsection{Normative grammars de facto and other languages}

The most influential English grammar in the period of the Enlightenment was Lowth (1762) ${ }^{31}$ It is said to have had more than 40 editions in the $18^{\text {th }}$ century, and the author is said to be the "embodiment of prescriptive grammar". ${ }^{32}$ It does not have a chapter on orthography, but it does have a chapter Punctuation on pages 168-184 (period, colon, semicolon comma, question mark, exclamation mark, and brackets). The grammar was first accepted by experts, while the schools used Ash (1763) as an adaptation of Lowth's grammar. ${ }^{33}$ This grammar does not have a separate chapter on orthography either, but in the end of the introductory chapter entitled An Introduction to the Grammatical Institutes. On the Alphabet, and the Sounds of the Letter, punctuation marks are listed on 3 pages:

\footnotetext{
27 A list of obligatory school manuals per grade and language in the Habsburg Monarchy can be found in Kovachich (1786: 593-600). It includes data on German, Hungarian, Slovak, Croatian (i.e. the Kajkavian dialect of Croatian), Illyric (i.e. the Shtokavian dialect of Croatian) and Romanian. Unfortunately, there are no data on Ukrainian and Czech.

28 The Shtokavian dialect won as the standard dialectal basis for Croatian half a century later, even though Kajkavian and Shtokavian Croatia were not united.

29 Lanosović's Shtokavian grammar from 1778 and the Kajkavian grammars of Ignaz Szentmartony (1783) and Franjo Kornig (1790) were written in German and were intended for foreigners. Their important common feature is that those were complete language textbooks for beginners, including conversation, dictionary, instructions for writing letters, etc. None of them has an orthographic chapter or orthographic content.

${ }^{30}$ This work had an amended edition next year (1780) with changed title: Napuchenye vu horvatzko pravopiszanye, Z pravochtenyem y glaszomerenyem, za potrebnozt narodnih skol Vugerzkoga y Horvatzkoga Orszaga. Leaving out the German part, in 1808 an amended work with a re-changed title was published Naputchenye za horvatzki prav chteti y piszati. Zkup z-peldami liztov y drugeh piszmeneh nachinov za potrebuvanye ladanyzkih skol vu horvatzkom kraljeztvu.

${ }^{31}$ We used the edition from 1763.

32 Tieken-Boon van Ostade (2000: 881)

${ }^{33}$ Stammerjohann (2009: 932). We used the edition from 1791.
} 
comma, semicolon, colon, period, question mark, exclamation mark, quotation marks (" or " "), brackets, caret, hyphen, apostrophe, paragraph mark (१), diaeresis and mark for note at the bottom of the page $(*,+, \neq$, or $\|)$. Capital and minuscule letters are also mentioned here.

In America, Webster (1783-1785) wrote a grammar in three volumes: the first was dedicated to orthography (Spelling Book) (1783), the second to grammar (1784), while the third part is a reader (1785). ${ }^{34}$ Expectedly, the first volume is primarily about pronunciation, although there is a description of orthographic characters on one page, representing the description of punctuation of the English grammar Brightland and Gildon (1711) with an added character for quotation marks, and leaving out the long line for omitted word. Orthographic marks are called Pauses and other characters used in writings, and those are comma, semicolon, colon, period, question mark, exclamation mark, round and square brackets, hyphen, apostrophe, caret, quotation marks ["], sign for note on the margin (index point 1 ), paragraph mark, section mark, (section $\S)$, and footnote mark $(*, \dagger, \ddagger$, or $\|)$. Interestingly, punctuation is located also in the appendix to the second grammar volume, spanning 6 pages, and it is, as is pointed out, „abridged from Dr. Lowth“.

The Portuguese Academia das Ciências de Lisboa is nowadays the official language regulator, however, historically viewed, as pointed out by Baxter (1992: 13), its function regarding language standard was more limited than the French and the Spanish one. "There are no grammars or complete dictionaries published by the Academia. Neither are there dictionaries or grammars sanctioned by it." ${ }^{135}$ An important role in language standardization was played by politician Sebastião José de Carvalho e Melo (Marquês de Pombal), under whose leadership numerous state reforms were conducted, including educational reforms in the spirit of the Enlightenment, known under the title Pombaline reforms. The official grammarian of the time was Antonio Jose dos Reis Lobato, whose grammar was published in $1770 .{ }^{36}$ It was used in colonies, and if it was not obtainable, Figueiredo (1799) was used instead. ${ }^{37}$ Lobato's grammar, following the traditional description of the Latin grammar, establishes orthography as part of the grammar (with prosody, etymology, and syntax), but it only describes etymology and syntax. The other mentioned Portuguese grammar does not deal with orthographic content either. Even though in the $18^{\text {th }}$ century seven Portuguese orthographies were published ${ }^{38}$, Portuguese had to wait until the $20^{\text {th }}$ century for its first official orthography.

Italy was not politically united in the $18^{\text {th }}$ century, so no educational reform for learning Italian could be conducted in a wider scope. According to the text of the Italian online encyclopaedia Treccani, Corticelli (1745) was the first Italian grammar with a clear educational function. Due to its use in schools, it was widely spread and had as many as 48 editions. ${ }^{39}$ It contains three parts, the third of which relates to orthography on 29 pages (Della maniera di pronunziate, e di scriver Toscano). The chapter includes a description of letters and sounds, pronunciation, accent, and syllables, and the writing of the apostrophe ( $4^{\text {th }}$ part), abbreviation of writing $\left(7^{\text {th }}\right.$ part $)$, compound and separate writing ( $9^{\text {th }}$ part), capital and minuscule letters $\left(10^{\text {th }}\right.$ part), and writing of period and comma ( $11^{\text {th }}$ part). The orthographic part in the narrower sense spans 8 pages. Here we can also clearly see the didactical dimension of the description of language in terms of rules, examples and exceptions.

\footnotetext{
${ }^{34}$ The edition from 1793 was used for the first volume, and from 1800 for the second volume.

${ }^{35}$ Stammerjohann (2009: 932)

${ }^{36}$ Leite (2011: 668)

${ }^{37}$ Cabral (2009: 221).

${ }^{38}$ According to https://hiphilangsci.net/2015/12/09/spanish-language-in-portuguese-texts-16th-to-19thcenturies/. Accessed on 10 February 2017.

${ }^{39} \mathrm{http} / / / \mathrm{w} w w . t r e c c a n i . i t /$ enciclopedia/lingua-del-settecento_(Enciclopedia-dell'Italiano)/. Accessed on 9 February 2017.
} 


\section{Orthographies outside of grammar books}

Although it did not have native speakers, Latin was in the $15^{\text {th }}$ and $16^{\text {th }}$ century still the language of science, so orthographic manuals from the $15^{\text {th }}$ and $16^{\text {th }}$ century had the role of an additional textbook on Latin. They were written for educated individuals who knew Latin. At a time when it had already lost the battle with vernacular languages in the $17^{\text {th }}$ century, orthographic manuals for Latin ceased being useful, making place for vernacular orthographies, so the evolutional shift is clearly recognizable. In addition to this, due to its intense orientation on antique sources and traditional orthographic descriptions, Latin orthographies were rather considered language guidebooks for reading antique texts than handbooks to increase literacy. A typical example of orthographic anachronism is the description of sentence marks (diple, obelus, and others), which were actually manuscript signs, not adapted to printed text. Orthographies had become independent publications at a time when interest for them appeared, and in the same way they also disappeared. As will be shown, the factors which had a major influence on Renaissance Humanism also influenced the development of orthographic books: translation of antique works, development of printing technology and spreading of the influence of the printed book.

The beginning of the orthographic description outside grammars is linked to the researcher of Latin, Giovanni Tortelli. As reported by historiographers, Tortelli was commissioned by Pope Nicholas V, humanist, protector of scholars and artists, to collect and translate Old Greek manuscripts. The collected texts composed the first materials of the Vatican Library, which was formally founded twenty years after his death (1475). Translation was not simple work and it craved great expertise, which lead to a very questionable quality of the first printed translations. ${ }^{40}$ Translators had to use at least two manuscript sources when translating because they often encountered with very different sources containing many mistakes, damages or gaps in the texts. The skill was to establish which text should be granted greater authenticity, harmonise texts of different length and description and connect the parts with the missing text, etc. In order to ensure this, translators had to use as many language, metalanguage, and historical information on the author and the text being translated as possible. As today, when antique texts are translated, translators needed manuals for transcription and transliteration, as well as encyclopaedic knowledge of its content. Thus came the interest in orthographic topics of the renowned publisher and editor of antique texts Aldus Manutius (1561). The goal of the first orthographic manuals was to standardize Latin spelling of Greek words and names, and to offer their phonological, etymological, and semantic description. With regard to its concept, Tortelli (1471) can be considered the first encyclopaedic and orthographic dictionary. ${ }^{41}$ Modern orthographic dictionaries, which come with orthographic manuals, have their roots in orthographic transcription manuals of Renaissance Humanism. Many later orthographic manuals of Latin inherit the structure of Tortelli's work. Contrary to Tortelli's extensive encyclopaedic work, later manuals were extremely popular because they inherited the structure of the very widespread antique and medieval genre - epitome - with short depiction of a particular topic, stating the sources and the review of relevant data, e.g. Latin textbook Valla (1510). Thus Manutius (1561 and 1566) are true orthographic textbooks: in addition to pointing to the typical mistakes in writing, pronunciation, phonological adaptation, original writing, etc., they include also quotations, sources, and reference information.

\footnotetext{
${ }^{40}$ „The first printed versions of the humanist translations in the later fifteenth and early sixteenth centuries are often very careless and, at times, downright dishonest, as were many early editions of classical texts in general.“ Fryde (1983: 85)

${ }^{41}$ The most exhaustive study on Giovanni Tortelli was written by Donati (2006), and the Commentariorum is also the topic of a two-year FP7-PEOPLE project (http://cordis.europa.eu/project/rcn/187898 en.html, accessed on 28 November 2016)
} 
Orthographiae ratio in the very end of the book describes punctuation marks on 8 pages - semicirculus (i.e. virgula or comma), semicolon, colon, punctum, interrogandi nota and parenthesis.

The need for a dictionary of names with basic data can be seen already in the fact that many medieval authors had several versions of their names (for example, Joannes Nemius, Jan Govertzoon and Jan Godevaarts represent one person).

After Tortelli and Valla, many Latin orthographic manuals were published, whose authors enriched and modified the orthographic description for different needs. In addition to the mentioned Manutius (1561), Victorinius (1527) described orthographic means for rhetorical and versification needs. Nemius (1572) adapted the concept of the orthographic manual to educational needs, referring thereby to numerous antique and his contemporary sources such as Priscian and Donatus, or Erasmus of Rotterdam and Ambrogio Calepinus. The orthographic description was also an appendix to the works for the needs of critical reading of antique authors. For example, De orthographia of Velius Longus, spanning 32 pages, was appended to the work Orsini (1587).

Numerous orthographic works were conserved owing to Elias van Putschen, who published Grammaticae latinae auctores antique in 1605, an extensive work spanning almost 3000 pages, a compilation of grammatical works of 34 authors. ${ }^{42} \mathrm{~A}$ similar compilation of works was published by Dilherri in Dilherri and Lipsius (1632). In this work, Lipsius published the treatise Orthographia secundum on 189 pages, with a list of names and adequate discussions divided into two groups, depending on the criterion of orthographic disputability, whose spelling "vel momentorum veterum fides vacillat" [shakes the memorials of old faiths]. Indisputable words were determined pursuant to the criterion if his predecessors agree in spelling, although there are also forms among the indisputable words, which were spelled differently by antique authorities (e.g. Dalmatia, not Lispius's recommended form Delmatia). ${ }^{43}$

Claude Dausque, French Jesuit, published in 1632 an extensive, structured and typographically strcutured work Antiqui novique Latii orthographica (second edition from 1677 has the amended title Orthographia latini sermonis vetu et nova). He represents important evolutionary progress in orthographic work and his work can be called the first orthographic manual of Latin in more modern interpretation. The work consists of two books: the first part with tractates or chapters on Latin orthography (210 pages) and the second part with an orthographic dictionary (348 pages). The first book consists of 7 chapters. The first chapter presents the authors, texts and books of the canon (names of 57 authors who wrote on orthography and the titles of the works). The second describes disputable letters in Latin and Greek ( $F, G, H, K, Q, Y, X, Z$, and $\Phi$ ), writing of letters in combination with other letters, and diphthongs. The third tractate refers to alternative spelling of certain forms, divided into several groups, e.g. according to phonology, morphology, parts of speech, lexicon, etc. The fourth tractate is dedicated to punctuation (signa interpuncta, seu positurae) and accents. Punctuation marks are the period, colon, semicolon, comma, question mark, and round brackets. The fifth describes sentence marks, showing that Dausque differentiates between sentence and textual marks. He calls the latter "sentence notes" (lat. sentintiarum notae), and under them he conveys some 30 antique marks (asteriscus, obelus, diple, antigraphus, etc). The sixth tractate is dedicated to abbreviations, taken over from Roman grammarian Marcus Valerius Probus from the $1^{\text {st }}$ century, whose work was published in 1502 under the title Grammatici de interpretandis romanorum. And finally, the seventh chapter presents Dausque's comments and supplements to Probus's abbreviations.

\footnotetext{
428 of 34 authors have the word orthographia in the title.

${ }^{43}$ In the first part of the list with indisputable spelling (De orthographia certa) there are 98 names, and in the second 27 names (De incertis).
} 
Dausque influenced the work of Christoph Cellarius, lawyer and historian, an extraordinary language purist, who mentions him in his preface to the work Orthographia latina from 1700 (other editions issued in 1704, 1710, and 1729). His orthography, spanning 70 pages, additionally forms and "modernises" the orthographic content with a chapter on letters and types of letters, sounds, signs for accents, punctuation (period, diaeresis [diacritica puncta], comma, semicolon, question mark, exclamation mark, round and square brackets), capital and minuscule letters, division of words, and abbreviations. The second part of work contains an orthographic dictionary spanning 60 pages.

After him, a Latin orthography was written by historian, professor and librarian Schurzfleisch (1707). The second edition is from 1767.

Portuguese Jesuit Azevedo (1747) wrote a short work in which the first part with seven chapters spans 22 pages and includes the description of capital and minuscule letters, writing of the letters $i / j$ and $u / v$, diphthongs, division of words, punctuation, and correct spelling. The second part with 11 pages is taken up by a dictionary, in which Azevedo compares orthographic solutions for spelling names from works of antique authors and other grammarians and orthographers (mostly from Manutius, Dausque and Vossius).

\section{Conclusion}

Grammars were the first framework in which orthography was described. As grammars changed, orthographic teachings also evolved. Since orthographic content, due to its nature, strives towards language fossilization, it is a good place to study the relation between the orthographical and the grammatical, that is the coming into being and the development of the standard. The analysis of grammars tries to answer the following questions: how do grammars view orthography (in the narrower sense), how did the orthographic content evolve, which are the roots of the orthographic standard, and can orthographic standard be reviewed in accordance with the grammatical function in the society which it served. Since, historically speaking, grammars often also had a normative function, in a way we are reviewing the historical relation between writing and literacy. It was shown that orthographic content reflects a grammatographic period in which it was created. Based on this, the framework is set for future sociolinguistic research on the relation between contemporary orthographic content and the development of writing today, and the importance of the orthographic standard for today's society.

This research on orthographic content in grammars of Rationalism and the Enlightenment follows a research on grammars of the Antiquity and the Early Middle Ages as well as the Late Middle Ages and the Humanistic Renaissance (Stojanov 2018).

Rationalistic grammars separated the orthographic description from grammatical teachings, breaking thus with the orthographic tradition of earlier periods, and such practice continued also in the Enlightenment. Contrary to rationalistic philosophical grammars, in which orthographic content was secondary since the centre of interest were speech and language universalia, in the Enlightenment it gains importance due to its role in spreading literacy and establishing the language standard. Orthographic content in both periods is mostly located at the very end of the grammar book or it already gets its own edition. (Traditional orthographic description starts from the description of orthography in the broader sense, with which the grammar begins).

The importance of Rationalism for orthographic content is that it emphasized the question of typography in the orthographic content (roman and italic letters), while the exclamation mark became a regular orthographic character. 
The definitions of grammars in the Enlightenment represent a deviation from rationalistic, philosophic grammars, because they bring back the goal of learning how to write and speak "correctly". As compared to the earlier period, grammar books are adapted to fulfil the social needs for harmonization of writing of that time. While orthographic literacy earlier referred to following the style of writing of certain language authorities, in the Enlightenment the secular government got actively involved in establishing a language standard. Regardless of how the orthographic content was published, within grammar books or independently, in all reviewed language environments (except for Portuguese) it was an important factor for establishing the language standard. Introduction of obligatory education contributed to the development of the methodology of grammatography. Since writing was closely connected to literacy, it is logical that grammars also included orthographic content. It was separated into special manuals the moment it started being considered an independent educational unit.

Great increase in grammar productivity with the rise of the middle class, which was to be introduced to the norms of correct writing and speaking, is clearly observable in the second half of the $18^{\text {th }}$ century. ${ }^{44}$

Since orthography, for the first time in history, gained clearly prescriptive properties, the Enlightenment is interesting also as a period when the influence of political government onto the orthographic standard can be followed, which will later prove to be a very interesting sociolinguistic area of research.

While vernacular grammarians in the $16^{\text {th }}$ century only poorly knew grammatical descriptions of other languages ${ }^{45}$, the example of the Habsburg Monarchy in the Enlightenment two centuries later shows an opposite situation with grammatographic uniformity - languages being described in accordance with the source language.

Based on 13 reviewed normative grammars from the Enlightenment in 11 language environments (German and English in two environments each: Prussia, the Habsburg Monarchy, England, and America), 7 of them describe orthographic content (English in England and America, German in Prussia, Polish, Russian, Swedish, and Italian), while 6 do not (Hungarian, Dutch, German in Austria, Portuguese, Slovak, Spanish). The reason why orthographic content is not found in normative grammars is twofold: either orthographic content had already been separated from grammatical learning and had grown independent in a separate publication (Spanish, Dutch, German in Austria, Hungarian, and Slovak) or orthographic content was not acknowledged as relevant grammatical content (case in Portuguese). It can be seen that normative orthographic manuals were issued parallel to normative grammars. ${ }^{46}$

In those normative grammars of the Enlightenment, which did have orthographic content, it spanned from 1 to 54 pages. If we exclude Adelung's grammar, which stands out substantially in the number of pages dedicated to orthography in the narrower sense, 7 pages are the average. The Enlightenment still does not differentiate between writing and speech, so the phoneme language dimension is equal to grapheme. This means that orthographic entities (in the broader or in the narrower sense) can be found also in different chapters, e.g. punctuation in the chapter on pronunciation in the grammars of Webster and Kopczyński. In most of these grammars, the orthographic content is located in its own

\footnotetext{
44 Tieken-Boon van Ostade (2008: 121). It presents a graph showing the ever increasing number of first editions of English grammar books and their reprints in the $18^{\text {th }}$ century, especially from the seventh decade of the $18^{\text {th }}$ century and on. Tieken-Boon van Ostade (2008: 106).

45 „Probably no grammarian of the period before 1700 even knew of the existence of more than a few grammars of languages other than the language he worked on." Rowe (1974: 364)

${ }^{46}$ In case of the Dutch and the Hungarians, it came out one year or three years before the grammar manual respectively, in case of the Austrian and Slovaks in the same year, and in case of the Spanish it came out two years later.
} 
chapter (one or several of them). Besides the Polish grammar, in which the orthographic content in the narrower sense is found in the beginning of the book, and the Russian grammar, where it is in the second chapter, all others end with the orthographic description. This information reaffirms the trend of separating the orthographic content from normative grammar books and making it independent. All 7 grammars assume orthographic content to include the description of orthographic characters, while other orthographic topics in the narrower sense are substantially less represented: dividing words (3 grammars), and capital and minuscule letters ( 2 grammars). The chapter on the apostrophe, general orthographic principles, abbreviation of writing, and separate and compound writing are found in only one grammar.

Contrary to the reviewed rationalistic grammars, which did not contribute substantially to the level of orthographic content, the normative grammars in the Enlightenment introduced many punctuation marks: four types of quotation marks (one single and three types of double quotation marks), several horizontal lines, caret, paragraph mark, section mark, sign for notes at the bottom of the page, etc.

In addition to new orthographic content in the narrower sense and substantially upgraded orthographic dictionaries, important novelty introduced by the Enlightenment is the form and the social importance of the orthographic manual. It was formed according to pedagogical criteria, so the rules became more structured, shorter and clearer. During the Enlightenment, orthography became standardized in most European countries, separating itself from grammatical teachings. Even though the $18^{\text {th }}$ century is sometime said to have "invented" language prescriptivism, this is actually not true. Even before the Enlightenment, orthographic prescriptivism can be seen in the common practice of defining grammars and orthographies as the "art of writing correctly". The Enlightenment only legitimized prescriptivism and endowed it with a normative and educational dimension. According to the criterion of legal obligation to implement the orthographic standard, orthographies can thus be divided into descriptive and prescriptive, with the Enlightenment as the boundary moment.

The form of the orthographic manual as we know today in languages with a tradition of issuing normative orthographic manuals, dates back to the time of the descriptions of Latin in Renaissance Humanism. Among the numerous orthographic works, two stand out as exhaustive, structured and typographically arranged: Dausque (1632) and Cellarius (1700). The reason for making orthographic content independent from grammatical teachings happened when the public's interest for them grew, and that was a time of greater production of written text and harmonization of writing, when the official language needed its rules. What was separated from grammar books as normative was just the question of writing - from spelling to orthographic characters. Typical grammatical topics such as morphology, syntax, and semantics remained in the grammar as descriptive knowledge. The moment of separation of orthographic content into an own edition is a good indicator of civilizational and sociocultural maturity of a particular society. It is not incidental that in many countries this happened just at the time of Renaissance Humanism.

Categories and classification of orthographic content were being considered back in Antiquity, while Rationalism brought a breakthrough towards the consideration of orthographic criteria. Thus, for example, Cartesian epistemology differentiates the forms of cognition per authority and per reason ${ }^{47}$, which is transferred to the orthographic and grammatical teachings as respecting tradition or following logics. These two criteria are considered essential in orthographic normativism even today.

The relation between orthography and authority is fundamental. We cannot speak about orthographic practice without a language authority. From the great orators and philosophers (Antiquity), over

\footnotetext{
${ }^{47}$ Ayers (2008: 1015)
} 
influential authors, aristocracy or translators of the Bible (Middle Ages and Humanism), in which authority was primarily created outside of the linguistic profession, to the Enlightenment, when the profession took over: authorized grammarians (German), language academies (Russian, Swedish), committees (the case in Poland), influential and renowned linguists (example of English and Italian).

It is interesting to study the interest of grammarians in orthography and of orthographers in grammar. Basically, grammarians studied orthography wishing to establish a written standard or to contribute to the discussion on writing in a language (e.g. Arnauld and Lancelot). On the other hand, for orthographers writing a grammar was a way to promote their own orthographic suggestions. For example, Petrus Ramus wrote a French grammar in 1562, in which he substantially changed the orthography, omitting all letters which were not pronounced and introducing new letters. A similar example is the English grammar of William Bullokar from 1586, who also tried to reform the English orthography. When the written standard was established, the interest of grammarians for introducing orthographic content decreased.

Equating the sound and the letter has been an orthographic constant from the first studied antique grammar of Dionysus Thrax. This non-distinction led to the insufficient precision of the term orthography today: archaism and term polyvalence leads to misunderstanding where, for example, the tem orthography is used both for spelling and for general studies of writing, e.g. punctuation, capital and minuscule letters, etc. Furthermore, the problem with the term orthography is that its etymological meaning has a prescriptive connotation. Research showed that the connection between the correct and the orthographic in grammars, historically speaking, is very strong. Moreover, this is why the meaning of orthography was widened to include correct pronunciation, although this is not related to writing. Many grammars describe the accents and correct pronunciation in the chapter on orthography. However, since speech is unstable, writing is visible and remains written down for the following generations, which is why it was given priority in forming and preservation of a language community. Especially outside of professional circles, but also even in professional circles, language changes are even today often considered to be unwanted, "language vulgarization" or deviation from the (eminent) tradition. The long tradition of the "correct language" in old grammars can probably be anthropologically explained by the binary division into correct and wrong.

The contribution of Latin orthographies in the later formation of normative orthographic manuals has only to a lesser degree been at the level of orthographic content, and more at the level of orthographic lexicography. Thanks to Latin orthographic manuals, which have developed and enriched this lexicographic form, modern orthographic manuals regularly include them. The orthographic content of Latin orthography books is only a thoroughly extended teaching of the orthographic chapters of grammar books.

Depending on the status of orthographic content in grammars, a new typology of orthographic and grammatical teachings can be established. The Antiquity first looks at orthography rhetorically, (ii) the Middle Ages and Renaissance Humanism semantically ${ }^{48}$ (orthography as a constituent part of grammar), (iii) Rationalism universally, and (iv) the Enlightenment prescriptively. It is interesting to note that Adelung is the first and only grammarian who used numerical marks for paragraph (§) throughout his entire grammar, which is a good depiction of the prescriptive methodology resembling the articles and paragraphs of law. ${ }^{49}$ Since Rationalism, orthographic content is no longer represented

\footnotetext{
${ }^{48}$ Kneepkens (2000: 551) speaks of the period of the Antiquity and the Middle Ages, in which grammar was basically semantically oriented.

${ }^{49}$ His large orthography from 1788 also had marks for paragraphs, however no unified numeration of the entire work, but separately per chapter. The marks for paragraphs are also found in modern European normative orthographies.
} 
one of the four grammar disciplines and lost its grammatical unit littera. The German grammarians and orthographers Adelung and Felbiger had a major influence on the form and content of the orthographic manuals today.

According to the criterion of motive for the creation of orthography, they can be divided into two phases: first is the technological aspect, and the second is the social one. The technological aspect of orthography relates to the spreading of written text, which fostered the harmonization of writing regardless of the fact if it was manuscript or printed text. Marking of the critical reading of Old Greek texts and the first punctuation marks are signs of the development of writing technology. On the other hand, the development of printing and mass production of identical texts logically led to the idea of a language standard, which facilitates reading and distribution of printed texts ${ }^{50}$, and thus it can also be called the technological motive for the creation of orthographies. This orthographic stage lasted until the Enlightenment. The social aspect concerns a language or political authority (individual, academy, secular government), which supervises the implementation of the orthographic standardization for the purpose of certain social interests (spreading of urbanization and the need of harmonizing a common language, political centralization, national ideology, reform of education, etc.). The orthographic practice to write orthographic manuals primarily for use in schools exists even today, because in this way language standardization is most easily implemented and supervised. The technological and social motive for creation of orthography can also be called two basic evolutionary orthographic points.

Keeping in mind the period of Antiquity, Middle Ages, Renaissance Humanism, Rationalism and the Enlightenment, it is impossible to give an unambiguous answer to the question on the relation of orthography to grammar, since its function changed through history and depended on the position of a particular language in a society and the way to look at grammatical teachings (basic division into grammatica positiva and grammatica speculativa). A long tradition of their relation surely exists and it can be said that orthography (as the way to write down speech) is as old as grammar. That first there was grammar, and then orthography is not to say that orthography arose from grammar, but that these two constituents were so closely connected in the beginning of western literacy that no difference was felt. Whenever grammar is defined as "the art of the correct", orthographic content can be expected to be found in it.

\section{Bibliography}

\subsection{Primary}

\subsubsection{Orthographies}

[anonimno]. 1779. Kratki navuk za pravopiszanye horvatzko za potrebnozt narodnih skol (Einleitung zur croatischen Rechtschreibung zum Gebrauche der Nationalschulen im Königreiche Kroatien)

[anonimno] 1780. Napuchenye vu horvatzko pravopiszanye, Z pravochtenyem y glaszomerenyem, za potrebnozt narodnih skol Vugerzkoga y Horvatzkoga Orszaga

[anonimno]. 1780. Přjwod ku Dobropjsebnosti Slowenského Pjsma k Prospěchu Mládeži Slowenských Sskól

[anonimno]. 1808. Naputchenye za horvatzki prav chteti y piszati. Zkup z-peldami liztov y drugeh piszmeneh nachinov za potrebuvanye ladanyzkih skol vu horvatzkom kraljeztvu

\footnotetext{
${ }^{50}$ Haßler \& Neis (2009: 700). Matasović (2016: 199) specially points out the printing centres of London, Paris, and Venice, which substantially contributed to the orthographic standardization of English, French, and Italian. ",[P]rinting of books has become a business, and printers had an interest to sell their products in an as large area as possible.“(translated from Croatian)
} 
Adelung, Johann Christoph. 1782. Grundsätze der Deutschen Orthographie

Adelung, Johann Christoph. 1788. Vollständige Anweisung zur Deutschen Orthographie

Azevedo, Emanuel. 1747. De orthographia

Cellarius, Christoph. 1700. Orthographia latina

Dausque, Claude. 1632. Antiqui novique Latii orthographica

Dilherri, Johannis Michaelis, Lipsius, Justus. 1632. Apparatus philologicae sive Justi Lipsii orthographia secundum

Felbiger, Ignjat. 1774. Anleitung zur deutschen Rechtschreibung: zum Gebrauche der deutschen Schulen in den kaiserlich-königlichen Staaten

Longus, Velius. 1587. De orthographia. In: Fulvio Orsini, Notae ad. M. Catonem, M. Varronem, L. Columellam

[Mandić, Antun]. 1779. Uputjenje k'slavonskomu pravopisanju za potrebu narodnieh ucsionicah u Kraljestvu Slavonie (Anleitung zur slawonischen Rechtschreibung zum Gebrauche der Nationalschulen in dem Königreiche Slawonien)

Manutius, Aldus. 1561. Orthographiae ratio

Manutius, Aldus. 1566. Epitome orthographiae

Nemius, Joannes. 1572. Orthographiae ratio

Putschen, Elias van. 1605. Grammaticae latinae auctores antiqui

Real Academia Española. 1741. Orthographía española

Révai, Miklós. 1778. A' Magyar Nyelvnek Helyes Írása, És Kimondása Felöl Kettös Tanuság, A vagy Ortografia a Nemzeti Oskolak számára

Schurzfleisch, Conrad Samuel. 1707. Orthographia romana

Siegenbeek, Matthijs. 1804. Verhandeling over de Nederduitsche spelling

Tortelli, Giovanni. 1471. Commentariurum grammaticorum de orthographia dictionum e Graecis tractarum libri

Valla, Lorenzo. 1510. Elegantiae de lingua latina

Victorinius, Marius. 1527. De orthographia

\subsubsection{Grammars}

[anonimno]. 1780. Přjwod ku Dobromluwnosti Slowenské: k Prospěchu Mládeži Slowenských Sskól

Adelung, Johann Christoph. 1781. Deutsche Sprachlehre. Zum Gebrauche der Schulen in den Königl. Preuss. Landen

Arnauld, Antoine, Lancelot, Claude. 1660. Grammaire générale et raisonnée

Arnauld, Antoine, Lancelot, Claude. 1975. General and Rational Grammar: The Port-Royal Grammar. Edited and translated with an introduction and notes by Jacques Rieux, Bernard E. Rollin, with a preface by Arthur C. Danto and a Critical Essay by Norman Kretzmann. The Hague: Mouton 
Ash, John. 1763. Grammatical Institutes

Beattie, James. 1788. Theory of Language

Beauzée, Nicolas. 1676. Grammaire générale: ou exposition raisonnée des éléments nécessaires du langage, pour servir de fondement à l' étude de toutes les langues

Brightland, John, Gildon, Charles. 1711. A Grammar of the English Tongue

Buffier, CLaude. 1709. Grammaire françoise sur un plan nouveau, pour en rendre les principes plus clairs et la pratique plus aisée

Bullokar, William. 1586. Bref grammar for English

Corticelli, Salvatore. 1745. Regole ed osservazioni della lingua toscana

Felbiger, Ignjat. 1774. Anleitung zur deutschen Sprachlehre. Zum Gebrauche der deutschen Schulen in den kaiserlich-königlichen Staaten

Figueiredo, Pedro José de. 1799. Arte da gramatica portugueza

Girard, Gabriel. 1747. Les vrais principes de la langue françoise

Gottshed, Johann Christoph. 1749. Grundlegung einer deutschen Sprachkunst

Kopczyński, Onufry. Grammatyka języka polskiego i łacińskiego dla szkół narodowych na klasę pierwszq, Warsaw, 1778; 1780 (... na klasę drugq); 1781 (... na klase trzeciq)

Kornig, Franjo. 1790. Kroatische Sprachlehre oder Anweisung für Deutsche die kroatische Sprache in kurzer Zeit gründlich zu erlerner

Lancelot, Claude. 1644. Nouvelle méthode pour apprendre la langue latine

Lancelot, Claude. 1655. Nouvelle méthode pour apprendre la langue grecque

Lancelot, Claude. 1676a. Nouvelle methode pour apprendre facilement et en peu de temps la langue espagnole

Lancelot, Claude. 1676b. Nouvelle methode pour apprendre facilement et en peu de temps la langue italienne

Lanosović, Marijan. 1778. Neue Einleitung zur Slavonischen Sprache mit einem nützlichen Wörter-und Gesprächbuche, auch einem Anhange verschiedener deutscher und slavonischer Briefe und einem kleinen Titularbuche versehen

Lhomond, Charles François. 1780. Éléments de la grammaire française

Lobato, Antonio Jose dos Reis. 1770. Arte da grammatica da lingua portugueza

Lomonosov, Mikhail Vasilyevich. 1757. Rossijskaja grammatika

Lowth, Robert. 1762. Short Introduction to English Grammar

Ramus, Petrus. 1562. Gramere de P. de La Ramee

Real Academia Española. 1771. Gramática de la lengua castellana

Régnier-Desmarais, François-Séraphin. 1706. Traité de la grammaire françoise 
Restaut, Pierre. 1730. Principes généraux et raisonnés de la grammaire françoise

Révai, Miklós. 1781. Magyar grammatika vagyis haza nyelvnek gyökeres megtanulására való intézet ugyan a magyar nemzeti oskolák számára

Roth, Georg M. 1799. Systematische deutsche Sprachlehre für Schulen

Sacy, Sylvestre de. 1799. Principes de Grammaire générale mis a la portée des enfans, et propres à servir d'introduction à l'étude de toutes les langues

Sahlstedt, Abraham. 1769. Swensk grammatika

Saussure, Ferdinand de. 2000. Tečaj opće lingvistike. [Course in General Linguistics]. Uredili Miro Kačić i August Kovačec. Preveo Vojmir Vinja. Zagreb: ArTresor naklada \& Institut za hrvatski jezik i jezikoslovlje

Scoppius, , Gaspar. 1628. Grammatica philosophica

Szent-Mártony, Ignaz. 1783. Einleitung zur kroatischen Sprachlehre für Teutschen

Tooke, John Horne. 1786. Epea Pteroenta, or The Diversions of Purley

Wailly, Noël François de. 1754. Principes généraux et particuliers de la langue française

Webster, Noah. 1783. A Grammatical Institute of the English Language. Spelling Book. 1784. Grammar. 1785. Reader

Weiland, Pieter. 1805. Nederduitsche Spraakkunst

\subsection{Secondary}

Ayers, Micharl. 2008. Theories of knowledge and belief. In: The Cambridge History of SeventeenthCentury Philosophy. Volume II. Edited by Daniel Garber and Michael Ayers. Cambridge University Press

Baxter, Alan N. 1992. Portuguese as a pluricentric language. In Pluricentric languages : different norms in different nations. Michael Clyne (ed.). Mounton de Gruyter

Buschmann-Göbels, Astrid. 2008. Bellum Grammaticale (1712) - A battle of books and a battle for the market. In: Grammars, Grammarians and Grammar-Writing in Eighteenth-Century England. Edited by Ingrid Tieken-Boon van Ostade. Mouton de Gruyter, 81-100

Cabral, Ricardo. 2009. The Development of Teacher Education in Portuguese Goa, 1841-1961. Concept Publishing Company

Chomsky, Noam. 1966. Cartesian Linguistics: A Chapter in the History of Rationalist Thought. New York: Harper \& Row

Deak, John. 2015. Forging a Multinational State: State Making in Imperial Austria from the Enlightenment to the First World War. Stanford University Press

Diderichsen, Paul. 1974. The Foundation of Comparative Linguistics: Revolution or Continuation? In: Dell Hymes (ed.) Studies in the History of Linguistics. Traditions and Paradigms. Indiana University Press, 277-306

Donati, Gemma. 2006. L'Orthographia di Giovanni Tortelli. Messina: Centro Interdipartimentale di Studi Umanistici.

Fryde, Edmund B. 1983. Humanism and Renaissance Historiography. The Hambledon Press 
Helden, W. Andries van. 2008. Vicissitudes of the Genitive Rule. In: Dutch Contribution to the Fourteenth International Congress of Slavists, Ohrid: Linguistics (SSGL 34). Edited by Peter Houtzagers, Janneke Kalsbeek and Jos Schaeken. Amsterdam - New York: Rodopi, 145-216.

Habermas, Jürgen. 2003. The Structural Transformation of the Public Sphere (1962). In: Paul Hyland with Olga Gomez \& Francesca Greensides (eds.). The Enlightenment: A Sourcebook and Reader. Routledge, 386-388

Juliard, Pierre. 1970. Philosophies in Eighteenth-Century France. The Hague: Mouton and Co.

Kneepkens, Corneille H. 2000. Linguistic description and analysis in the Late Middle Ages. In: History of the Language Science. Vol. 1. HSK 18.1. Edited by Sylvain Auroux at al. Walter de Gruyter, 551-559

Kovachich, Martin Georg. 1786. Merkur von Ungarn: oder Litterarzeitung für d. Königreich Ungarn u. dessen Kronländer. Pest

Leite, Marli Quadros. 2011. A construção da norma linguística na gramática do século XVIII. Alfa : Revista de Linguística. (São José do Rio Preto), 55 (2). São Paulo July/Dec. 2011.

Marker, Gary. 1994. Faith and secularity in eighteenth-century Russian literacy, 1700-1775. In: Robert P. Hughes, Irina Paperno (eds.), Christianity and Eastern Slavs: Volume II: Russian Culture in Modern Times (California Slavic Studies 17), 3-24. Berkeley-Los Angeles-London: University of California Press.

Marsden, William. 1796. A Catalogue of Dictionaries, vocabularies, grammars, and Alphabets. In Two Parts. London

Noordegraaf, Jan. 2000. Normative studies in the Low Countries. In: History of Language Science. An International Handbook on the Evolution of the Study of Language from the Beginnings to the Present. Volume 1. Edited by Sylvain Auroux et al. Walter de Gruyter, 893-900

Nyomárkay, István. 2000. Kroatističke studije. Zagreb: Matica hrvatska

Parkes, Malcolm Beckwith. 1992. Pause and Effect. An Introduction to the History of Punctuation in the West. Ashgate

Rowe, John Howland. 1974. Sixteenth and Seventeenth Century Grammars. In: Dell Hymes (ed.) Studies in the History of Linguistics. Traditions and Paradigms. Indiana University Press, 361-379

Stammerjohann, Harro. 2009. Lexicon grammaticorum. A Bio-Bibliographical Companion to the History of Linguistics. Second Edition. Max Niemeyer Verlag

Stojanov, Tomislav. 2018. Orthographies in Grammar Books - Antiquity and Humanism. Preprints 2018, 2018070565 (doi: 10.20944/preprints201807.0565.v1)

Swiggers, Pierre. 2001. Grammar. In: Encyclopedia of the Enlightenment. Edited by Michel Delon, Vol. I A-L. Routledge, 617-622

Teleman, Ulf. 2005. The role of language cultivators and grammarians for the Nordic linguistic development in the 16th, 17th and 18th centuries. In Oskar Bandle, Kurt Braunmüller, Ernst Håkon Jahr, Allan Karker, Hans-Peter Naumann, Ulf Teleman (eds.) 2005. The Nordic Languages. An International Handbook of the History of the North Germanic Languages. Volume 2. Walter de Gruyter, 1379-1396

The Age of Enlightenment. An Anthology Prepared for the Enlightenment Book Clup. http://www.rosenfels.org/The_Age_Of_Enlightenment_Anthology.pdf 
Tieken-Boon van Ostade, Ingrid. 2000. Normative studies in England. In: History of Language Science. An International Handbook on the Evolution of the Study of Language from the Beginnings to the Present. Volume 1. Edited by Sylvain Auroux et al. Walter de Gruyter, 876-887

Tieken-Boon van Ostade, Ingrid. 2008. The 1760s: Grammars, grammarians and the booksellers. In: Grammars, Grammarians and Grammar-Writing in Eighteenth-Century England. Mouton de Gruyter

Verburg, Pieter Adrianus. 1998. Language and its Functiones. John Benjamins Publishing Company

Vinja, Vojmir. 2000. In Lancelot, C. Opća i obrazložbena gramatika = Grammarie générale et raisonnée de Port Royal. Hrvatsko izdanje priredio i komentarom popratio Vojmir Vinja. Zagreb: Institut za hrvatski jezik i jezikoslovlje

Williams, James D. 2005. The Teacher's Grammar Book. Lawrence Erlbaum Associates, Publishers Second edition 